\title{
The Response of the Mexican Economy to Policy Actions
}

\author{
by GILBERTO ESCOBEDO
}

\begin{abstract}
Mr. Escobedo is the Assistant Director of the Department of Economic Studies at the Banco de Mexico. He majored in economics at the Universidad Nacional Autonoma de Mexico and attended the Universidad Iberoamericana and Florida State University for additional study.

He has written extensively on the Mexican economy. While on sabbatical leave to the Federal Reserve Bank of St. Louis, he directed his attentions to the development of an econometric model of the Mexican economy. The following article serves as supportive material to this econometric study.
\end{abstract}

\begin{abstract}
T
HE MEXICAN economy has experienced a remarkable evolution in the last decade. Compared to the western world, Mexico's rate of growth in this period was surpassed only by Japan, and the rate of inflation was low and steady. This is to mention only two of the many economic accomplishments of the nation that has been referred to as "The Mexican Miracle."

For some people, however, the days of the socalled "Mexican Miracle" seem to be ending, while for others only temporary difficulties have appeared. In 1971 the rate of growth of real gross domestic product (GDP) reached its lowest point since 1955 (3.7 percent) and prices showed a peak rate of increase of 5 percent." The question now asked is whether this situation was just a temporary setback or a sign of things to come.
\end{abstract}

This article attempts to provide some insight into the complexities of the Mexican economy. It serves as background information to a larger study on the development of an econometric model of the Mexican economy.



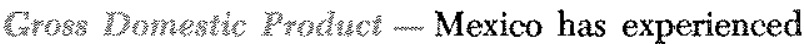
considerable economic growth in the last 15 years.

1Gross domestic product is equal to gross national product minus factor payments to other countries.
Gross domestic product has grown at an average annual rate of 11 percent, 7 percent in real terms and 4 percent in prices. $^{2}$ When considering the 3.2 percent rate of population growth, output per capita rose at a very respectable 3.8 percent rate. ${ }^{3}$

The composition of GDP has undergone a considerable change in the last 20 years. As a result of import substitution, manufacturing production has grown considerably in importance at the expense of agriculture. Over the same period services have grown and at present represent more than 40 percent of total GDP.

In spite of the rapid growth and shifts in the composition of production, an underlying problem of persistent maldistribution of income has shown no relative improvement in the past 15 years. ${ }^{4}$

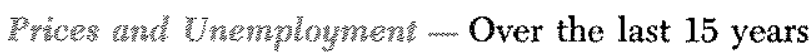
the 4 percent annual rate of growth in the implicit price deflator compares favorably with the 10 percent yearly average of the previous 15 years. Inflationary pressures in this earlier period primarily reflected a rapid growth in Federal expenditures relative to na-

\footnotetext{
${ }^{2}$ The data used throughout this section are from the following sources: Banco de Mexico S.A., Direcion General de Estadistica, and Intemational Monetary Fund.

3Output per capita in terms of dollars has grown as follows: $1950=\$ 183 ; 1960=\$ 346$; and $1970=\$ 690$.

Iffgenia M. de Navarrate, La Distribucion del Ingreso y el Desatrollo Economico de Mexico, UNAM (1960).
} 


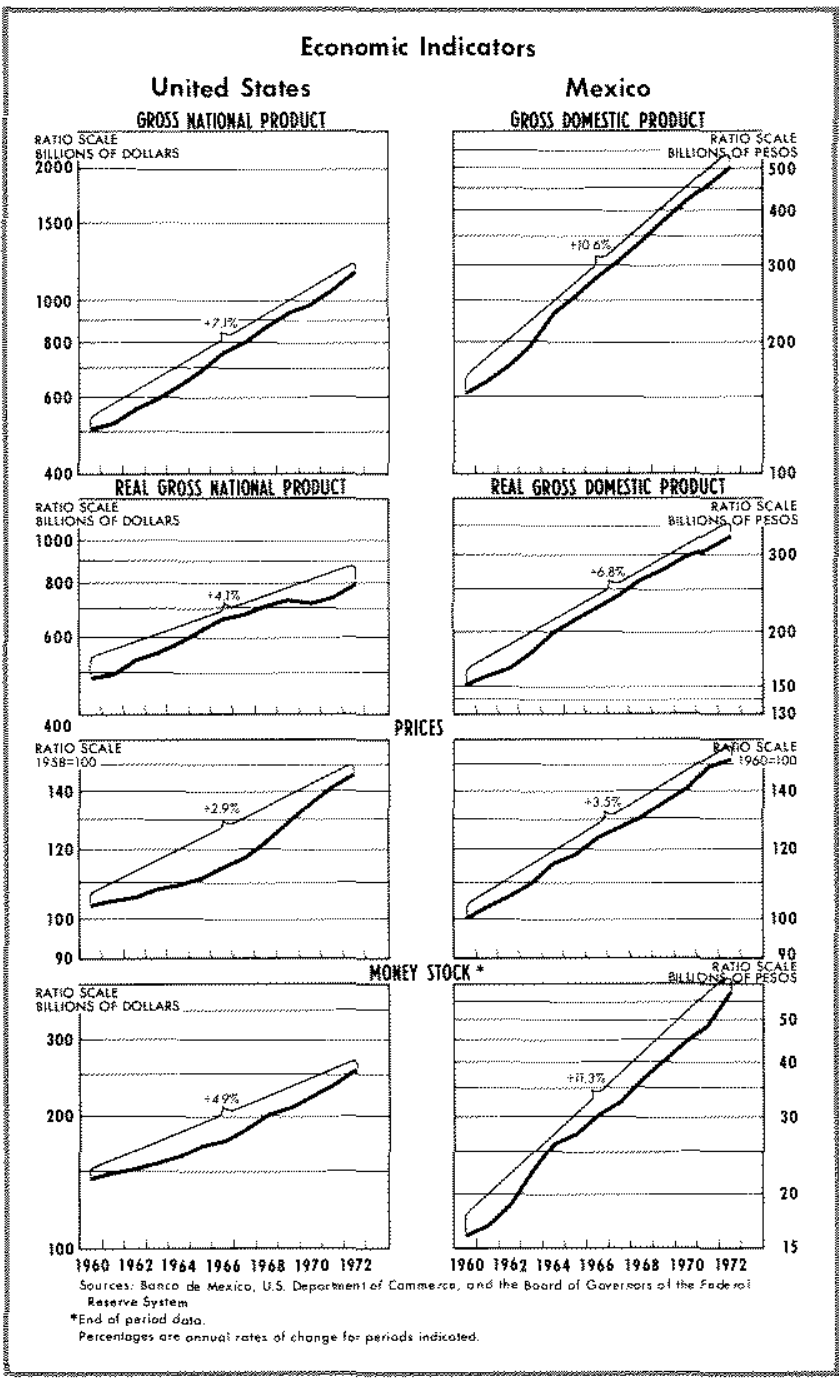

tional output. These expenditures were financed by the creation of "new" money which grew at rates higher than real GDP.

Stability in the more recent period has been accomplished by maintaining balance between Federal expenditures and national output. Monetary authorities have contributed to this delicate balance by offsetting pressures emanating from excessive Government expenditures and an important external sector.

The rate of unemployment in Mexico is generally considered so high that sharp increases in aggregate demand are assumed not to affect prices, since they will be absorbed by greater levels of employment. This assumption can not be proved, however, since there is no reliable information concerning employment. As developed later, it will be shown that for certain instances, full-employment conditions appear even though a great proportion of the labor force is actually unemployed.

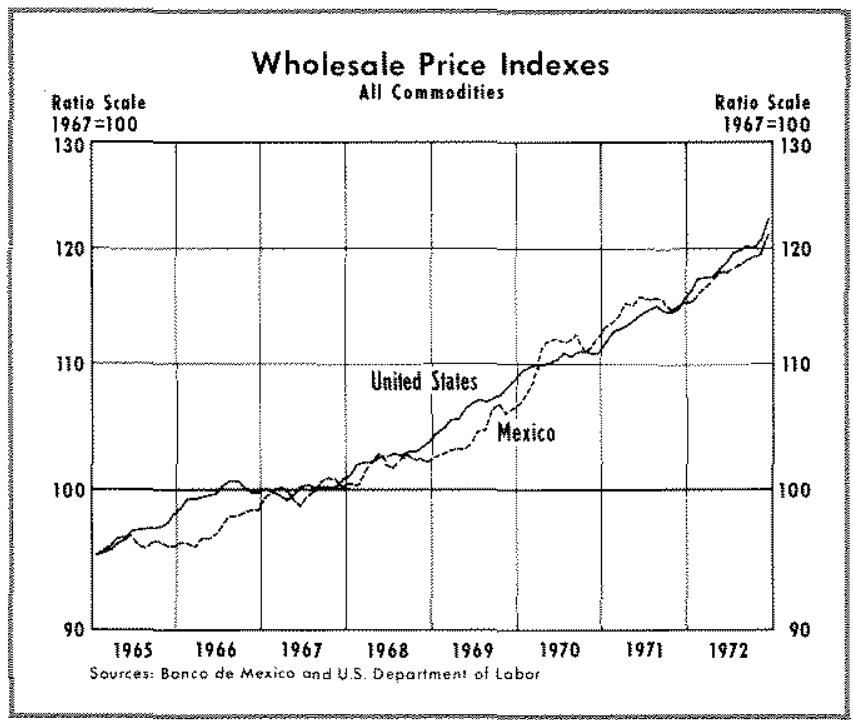

Tnestment - Real investment has been the main source of dynamism in the Mexican economy. Public as well as private capital formation have made it possible to achieve an average 17 percent annual rate of growth in real investment in the last 20 years. Over that period Government investment, directed mainly to the development of infrastructure (roads, dams, electricity, etc.), has comprised about 45 percent of total investment.

Puble Finance - Throughout the past 10 years the annual rate of growth of total Government expenditures has been 13 percent. This growth is primarily the result of a public policy to accelerate infrastructure capital formation and promote social welfare. On the other hand, revenue has not grown at a rate suffcient to cover total expenditures. Consequently, the net budget position has been in deficit.

The relatively slow growth in revenue represents a direct effort by the Government to promote and sustain the growth of private investment, rather than increase Government revenue. Tax exemptions or reductions as well as increased transfer payments have been used widely to promote private investment, both domestic and foreign.

Savings - While Federal Government contributions to the growth of savings (budget surpluses) bave been negligible, private as well as foreign savings have been growing at high and steady rates. Gross national savings grew from 4,735 million pesos in 1950 to 12,442 million in 1958 , and to 52,000 million pesos in 1970.5 Savings represented 10 percent of GDP in 1950 and 17 percent in 1970.

5 One peso is equivalent to $\$ .08$ in U.S. currency. One dollar is 12.50 pesos. 


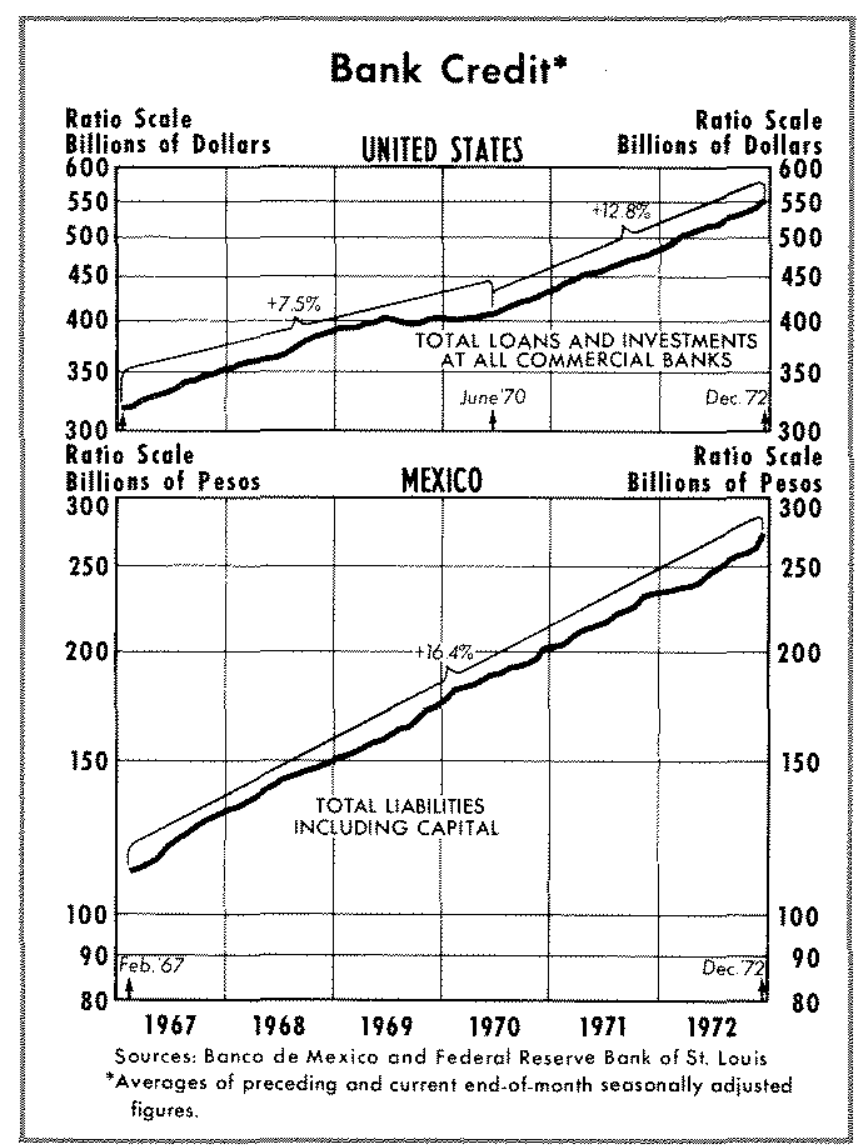

The Mexican banking system has been absorbing greater amounts of these savings in the last 15 years. Its liabilities have been growing at an average rate of 17 percent annually - a rate considerably higher than that of GDP. Increased monetization of both real and fnancial assets and growing domestic savings permitted this growth in banking liabilities. The favorable interest rates relative to foreign markets, and a competitive and efficient financial system produced attractive conditions for domestic as well as foreign investors.

The greater volume of savings received by the financial system, in turn, has allowed monetary authorities to reallocate private savings to finance Govemment deficits through the mechanism of required reserves, instead of issuing "new" money. (Growth of the money stock has been sustained at an average annual rate of 10 percent in the last 15 years, the same rate as nominal GDP.) Although this reallocation process has increased the amount of credit available to the Government, it also has made the Government more dependent on private banking.

Futersal sector - One of the great problems facing any developing nation, including Mexico, is financing the increased importation of required capital goods.

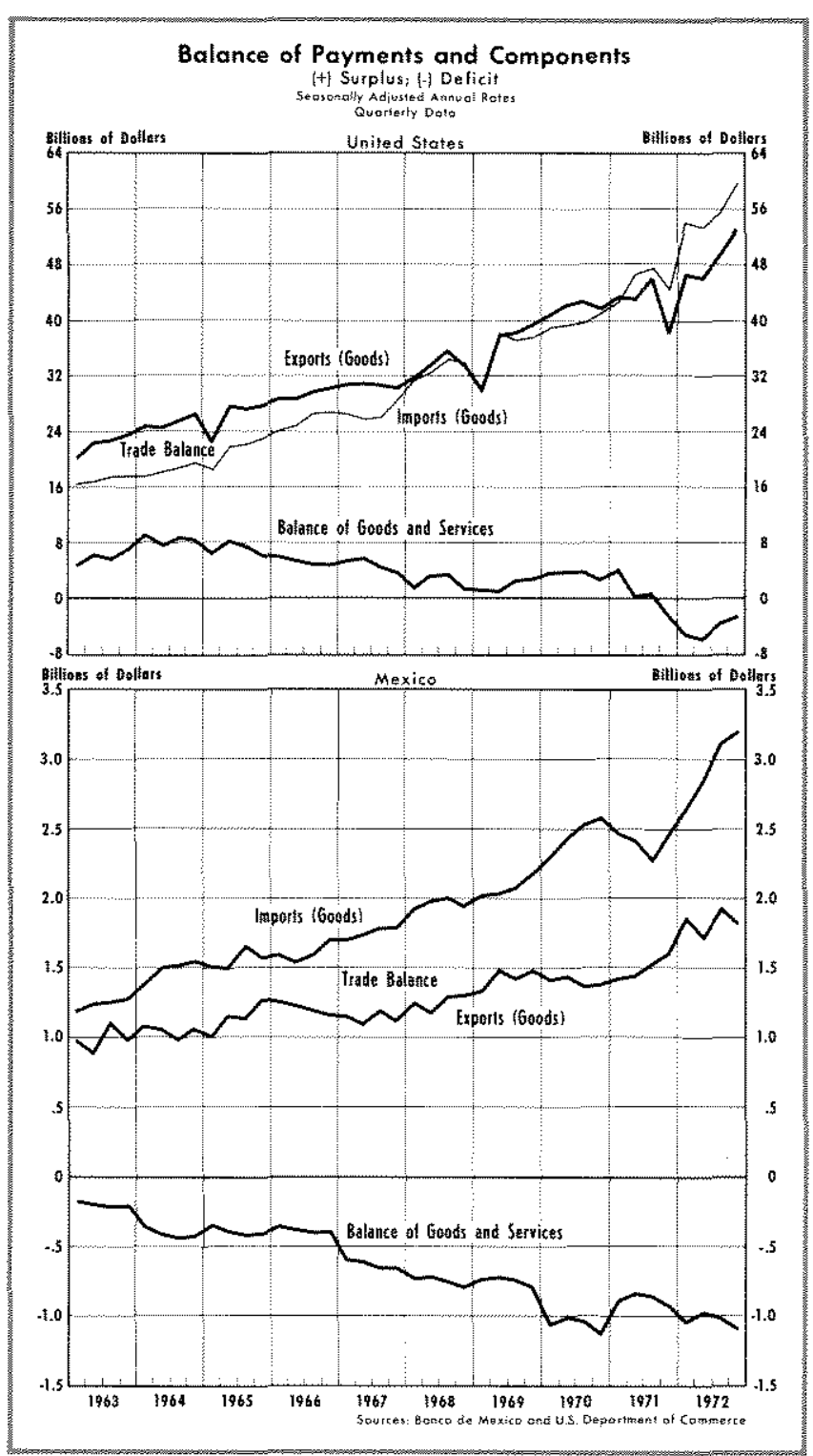

Mexico's imports, which currently represent 15 percent of $\mathrm{GDP}^{6}$, have increased at an average annual rate of 12 percent in the last decade. This rate is not only higher than that of GDP, but also exceeds export growth, which has been growing at an average annual rate of only 8 percent. As a result, the balanceof-payments deficit on current account has been increasing continuously, reaching a peak of $\$ 900$ million in 1970 .

The increasing trade deficits have been offset by greater direct foreign investment and loans. Until now the amount of foreign credit has not only been suffcient to finance the current account deficit, but enough

IIn the United States this proportion has been approximately 6 percent of GDP in the last three years. This proportion in Mexico seems high considering that the process of import stubstitution has practically come to an end. 
external capital has been received to allow an expansion of the international reserves of the central bank.

Recognizing that the development process itself requires increasing amounts of imports, the only solution to a trade deficit problem for a developing nation is to promote exports. Exports of agricultural products do not provide the long-run solution for Mexico since they have only been growing at 4 percent annually a situation that cannot be expected to change significantly given the technical disparity of agricultural production. It is understandable, then, that vigorous private and public efforts have been directed toward the promotion of exports of manufactured goods and to the promotion of tourism.

\section{Economa Polloy Oblectures}

Mexico, as any developing country, required substantial public capital formation in the early stages. As the private capital markets became more developed, provision for such capital goods has increasingly become the responsibility of the private sector, both foreign and domestic.

A public policy directed toward capital formation and better income distribution explains increased Government involvement in the economy. The important role of the Government in economic activity qualifies the Mexican system as a "mixed" or "national" capitalism. Nevertheless, this participation has not reached the proportions of other industrial or less developed countries.

Government intervention in the economic process through policy decisions has had a long tradition in Mexico. Policymakers always have been remarkably sensitive to political and economic forces. Even without sufficient technical knowledge, they adopted policies which allowed Mexico to sustain a continuous pattern of growth.

Recently more sophisticated techniques have been used. However, the natural impulse of the policy. maker still has considerable weight in the final decisions, sometimes invalidating the technical advisors' recommendations.

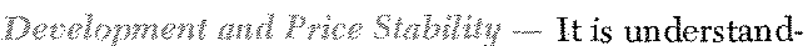
able that economic development is, and has been for some time, the main economic policy objective. In

In Mexico, this problem is commonly referred to as the "dual agrieulture" system - one segment utilizing modern farming techniques and another segment relying on relatively primitive techniques. the past this goal was expressed in general terms, rather than specifically quantified. Presently it is expressed as a "desired" annual rate of growth in real GDP between 6 and 7 percent. When adjusted for population trends, this means a net growth of 3 to 4 percent in per capita terms.

Until 12 years ago no goal other than fulfilment of development was considered important. Then with the awareness that continued inflation and drainage of foreign exchange were inhibiting real growth and aggravating the problem of income distribution, the need for price stability became evident. Beginning in 1955 policymakers introduced price stability as an ultimate objective to accompany the development goal.

The price stabilization goal pertains to both domestic and international purchasing power; that is, the rate of growth of domestic prices should not deviate substantially from its long-run annual trend (3 percent) and the rate of exchange of Mexican currency should be maintained. According to policymakers, both goals should be accomplished under conditions of free internal markets and free convertibility of the peso.

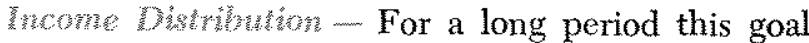
remained of secondary importance. There was a wide belief that in the long run economic growth and increased savings would eventually raise general income, thereby increasing everyone's welfare position.

Time has proven that even though the process of growth with stability has been relatively successful and the welfare position, on average, has improved, this actual distribution of income is no better than 15 years ago. One explanation is that promotional measures directed towards capital formation have implicitly encouraged the concentration of income. Promotion of savings and investment through tax exemptions and subsidies has favored higher over lower income groups. The unemployment problem also hindered income distribution as the extensive use of technology imported from developed countries reduced the domestic demand for Mexico's most abundant productive factor - labor.

Therefore, the redistribution of income target has appeared explicitly in Mexican economic policy. It remains uncertain whether it is possible to make economic growth compatible with greater income equity and price and exchange rate stability. This problem is confronted later when the experience of 1971 is detailed. 
Cmplotymon - Until recently, this goal was never explicit in Mexican economic policy. In fact, one could say that for a long time it was neglected, although a wide consensus conceming the problem has existed and can be traced in Mexican economic litera ture. Employment now is probably the main concem regarding fulfillment of the income redistribution goal.

For many years labor market conditions aided in the goal of price stability. There was an abundant supply of labor at relatively low salaries. Union power was, to a certain extent, influenced by the Government. These conditions allowed wages to grow slower than productivity, thereby facilitating price stability.

The situation has changed somewhat since the mid1960 s because the unions have gained political power, increasing considerably not only workers' salaries but also social and "fringe" benefits. The higher salaries resulting from the bargaining process, however, have not been reflected entirely in prices since productivity has continued to grow at high rates. Moreover, the benefits of unions are only available to limited groups of workers, and the supply of unskilled labor is still large relative to demand.

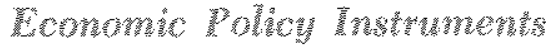

Fiscal and monetary policy have played an important role in attaining growth and stability in the last 15 years. The short-term policy instruments available to policymakers to fulfill these objectives are mainly taxes, Government expenditures, and changes in the supply of money and credit. Import controls could also be used for this purpose, but such controls would be rigid and subject to many bureaucratic processes that would render them extremely ineffcient for short-run policy.

Fistall Policy - Fiscal policy has contributed to both growth and price stability through different means. To prevent prices from rising to levels harmful to low-income groups, price ceilings have been established mainly on basic foods. When certain prices tend to rise above the level set by the controls, the Government will import such goods and allocate them in the domestic market, forcing observed prices to remain in check. ${ }^{8}$

In the early stages of development, high tariffs were enforced on imports of so-called "luxury" and domes-

8Price ceilings, athough quite ineffective in controlling real price increases, are a valuable political asset in terms of their effect upon public opinion. tically-competing goods. The domestic producer was artificially protected so he could develop a product competitive in quality and price with that imported. Advances that were made in the import-substitution process have reduced the need for protective tariffs, which are unfavorable to domestic consumers anyway. The fiscal authorities have also given tax incentives to new industries by reducing, or in some eases eliminating, indirect or income taxes.

These measures have indeed promoted growth in domestic production. However, the main contribution of fiscal policy has been the pattern of Government expenditures, which essentially is an autonomous variable. Nevertheless, the approval of each ministry's budget is subject to close economic considerations, especially when it is an investment expenditure. The views of the Treasury and the central bank are considered before the budget is sent to Congress for final approval.

Monetary Wolicy - As mentioned earlier, the higher rate of growth of expenditures relative to revenue is annually reflected in Govermment deficits. Once the budget is approved the monetary authorities must decide what sources of funds will be used to finance the Government deficit. First, an estimate is made of how much credit will be available from foreign sources. After this is determined, the rest must be financed with domestic credit. The external funds take the form of either loans or foreign investment. The latter, not available for financing budget deficits, has been following a steadily growing trend in the last fifty years. ${ }^{8}$

Another important source of funds is foreign savings attracted to the Mexican banking system by the high rates of interest paid in comparison with international standards (see the accompanying chart). The interest rate differential together with the political and economic stability that Mexico has attained in its development process have acted as incentives for large amounts of savings (estimated growth is more than 3750 million pesos annually). ${ }^{10}$

\footnotetext{
"Sixty percent of this investment, on the average, comes from the United States. Although foreign investment is still grow ing in absolute terms, the rate of growth has slowed in the last two years, due mainly to the slower GDP growth experienced in $197 \mathrm{I}$ and to the fact that fewer sectors remain for new, highly profitable investment. That is, corporate profit rates, in general, are not as great today as they were twentyfive years ago. Economic development has reduced retums on investment, but at the same time has made these return less vulnerable to hinge swings in either direction.

isee the screened insert to this article for a description of the Mexican banking system.
} 


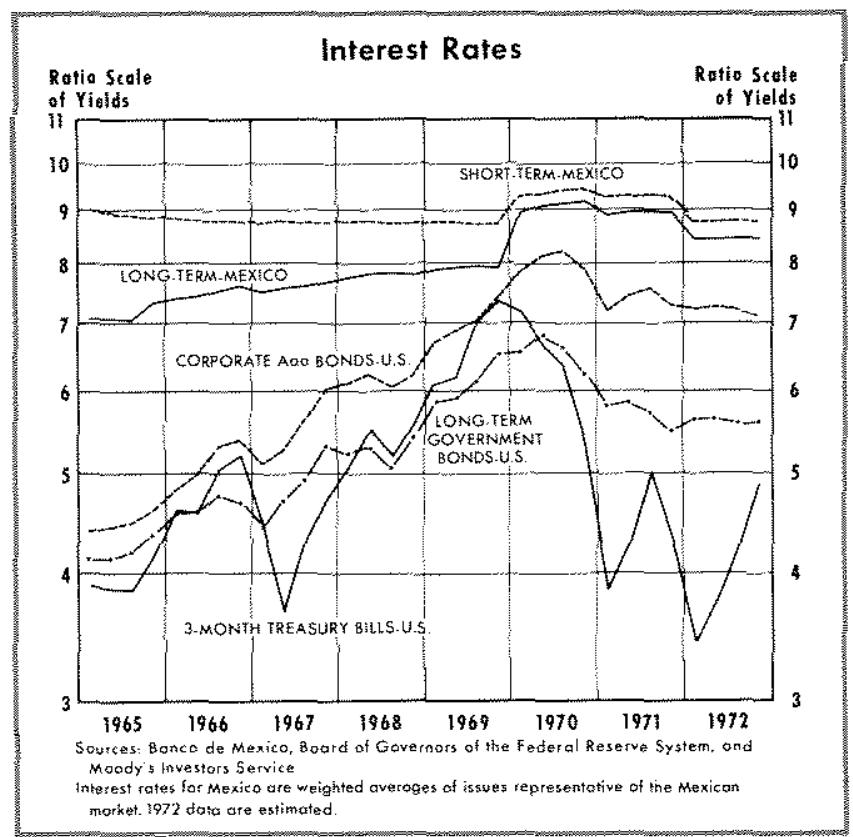

These foreign savings, besides helping to finance the current account deficit of the balance of payments, are used to finance budget deficits. Required reserves on commercial and investment banks must be invested in Government bonds or in seleoted sectors of the economy to meet the regulations that govern the Mexican banking system. Since these legal reserves are imposed on all the funds that banks receive, the funds are used for Government financing regardless of their origin. ${ }^{11}$

Another channel through which foreign funds are obtained to finance Government and balance of payments deficits is short- or long-term loans. These funds are usually linked to specific Government investment projects.

If the amount of foreign plus domestic funds available were enough to finance the Government deficit, the central bank would be in a neutral position, neither expanding nor reducing international reserves. If all of these funds were not enough to finance the Govemment deficit, the central bank would have to consider direct credit to the Treasury, even at the risk of overstimulating total demand. If the threat of over-stimulation became very serious, the central bank would have to take compensatory action on private credit so that the nation's overall objectives would not be endangered. The central bank action would entail a reduction in bank credit to allow

\footnotetext{
${ }^{11}$ Legal reserve requirements can be as high as the monetary authorities decide. On the average, they have been $18 \%$ for conmercial banks and $35 \%$ for investnent banks and nonmonetary liabilities of commercial banks.
}



Mexico's stock of international reserves to remain unchanged, thus assuring the goals of stable exchange rates and free convertibility.

Summing up, one could conclude that Government expenditures are the main exogenous variable in the short term. Monetary authorities are left in a rather compromising situation - either reduce the amount of funds available to the private seotor or lose foreign exchange.

\section{Devalopmen, Towenn Fxhange and Proe Sabinty oncompande Goals?}

The objectives described have an inherent tendency toward disequilibrium. The price stabilization and development objectives are, to a certain degree, opposed when one of these goals is pursued vigorously over the other.

The development goal requires that output grow at the highest annual rate possible. Government expenditures are therefore promoted so that increased total demand will act as an incentive for private investment. This level of expenditures promotes an increase. in real output as long as the economy is not at full employment. 


\section{Present Structure of the Mexican Banking System}

The Central Banle (Baneo de VIexieo) has been Whe foed point of the nonetary sustem. On the one hand, it performs the taditional duties of a central bank, stueh as issing curency, super vising the bank. ing system and advising the Goveriment on monetary and credt policy. In addition, ot has assinined hic non traditional function of rediecting the how of credit 10 spectic sectors. Sont ach hilles, sud. as agreullure, have reeened this preferential treatment bechuse wheir rale in frifling lhe Governments god of developnert is geverally regarted as essential.

The most importint realloction of credit howeder. is a result of the centrat bauks postion in financing Covernment deficits. Through the nechamism of legal reserve requinements, the centrat bank allocates Gov. emment domestic debt in the banking systen. The funds placed on deposit at 1 he central bank ror re: serve requirerient pirposes are ised to purchase high-uldd Goverminent bohas. In addition to com nerchl banks, the eentral bank exterds the procedure to the reserves of mvestment barks also. As a result funds avaluble to the Govermment through reserve requirements represent about 25 to $30 \%$ of total 1 . abilities of the mancial system?

As is probably evident, Whe allocation and aval ability of credit is the primary concern of the central bank Unllke monetary policy in the United States. the cost of credit is not given a great deal of attention in Mexico. As a result the level of interest rates in Mexico is not a very reliable ndicator of central bank activity?

The National Gredit Institutions are hose finaheial internedhares either parth or wholly owned by the Govennment, Allough considerably less. impontant than they were 15 years ago, hlese institutions still play a fundamental role in the economy. They were ongi. nally establisled to give spectill prionity hit the alloea. hon of domeste and foretgr eredit. Their funds have been directed nainfy to agriculture, to 'infant' indus ines, and for llie promotion of Mexiean exports.

These institutions compele wilh private commercial and investment banks for the savings of the pablic In addition they are allowed to issue debt to the foreign public, for which there is Govennent assurance of payment The finds received are allocated at lower interest rates and longer maturities than those pre valling in the natket, Which is, generally reffected in a lower proftablity for these banks. 1,osses incurred by these institutions are covered in the Government's budget:

1Nonbanking institutions are another source of finds for finatich government debt Insurance companies and trust fund organizations for example, are reguired by law to hold a certain porton of their financial assets in some form of puble debt inst tument
Prvate tinancial Intemediaries, which account for

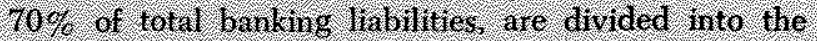
following finctiond tategoriest as deposit and sav.

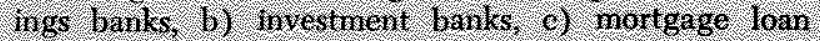

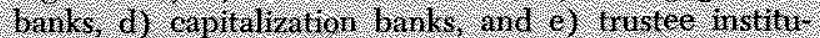
tions 411 these instithons operate inder the jurisdic. Von of lhe Minitry of Pinarae throigh the National Bhining Cominission. The Briteo de Mexico is, how ever. 1 te 1 minary bank regulator

a) The deposil and strings banks constitule the

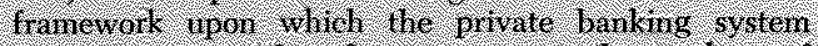
hi Nesico rests. Ther functions are similar to those of at commeredal bank in the Urited States. Redecting the dentaid for the triativel simple instruments Whit these instivitions supplied. We depasit and savings lavks experienced cubstantial growlth between 1940 and 1955 . Todat the banking structure has changed and these banks lave lost importance in relative terins. However, they stil hold a ligh volime of savings in absolute tems.

b) Dhing the last 10 vears he nvestment lanks. Financietas? hate atanined a spectacular growth. Oingually the 'fhancicras' issued longterm paper. But the strong preference of the publie for liquid assets $\mathrm{h}$ s wesulted in the tssranee of sight payable bonds carving an 8 s percent interest rate. As piblic confidence grew, 1 was possible lo issie paper with longer natwities and high yields, sudh as "reertificados fintrateros" These instriments generally pay an itter est rate of 10 percent annually with a 10 year ba inity This type of paper expanded rapidy from its introduction ho 1966 until 1960

The instablily of the international monetary mar kets since 1960 has created a greater domestie denand for highly liquid paper with high yilds. This. development has pulled ho "finaneteras' back on the money market, instead of ine copital mathet for which Hey were originally intended.

c) The nortgage lbanks are sinilar in fanction to US. saling and lom associations. The main instrur rents employed by these banks are bonds and "cedulas lipotecarias: The litter are a form of moit. gage secured not only by real estate, but also by the guarantee of issuing mortgage bahks. These instruments offer a combination of Iigh liguidity and a field averaging around 8 percent.

d) The so-ealled capitalization banks, onginally de. veloped to ret as savings banks, have been unable to compete effectively for funds. As a result, they have not grown in either number or total assets.

e) The Merican banking system is supplemented hy a number of financial histitutions sueh as insurance eompanies, soctal secunty tinst fmds, and other auxHary institutions. These institutions either issue finan clat clains or facilitate the flow of financial resomees between the vartous sectors of the economy. 
It is generally assumed that Mexico has a high rate of unemployment. Consequently, increases in aggregate demand would not affect prices but would promote production of more real goods and services. This sometimes is not the case, however, because the typical unemployed individual is not sufficiently skilled as to be utilized when more output is desired. Therefore, price stability and high rates of growth can be conflicting goals. In order to finance the increased level of Government expenditures, the central bank must either create new money or reduce the amount of credit available to the private sector. If new money is created in excess of the prevailing trend, additional pressure is exerted on prices. Consequently, the central bank usually prefers to reallocate the sectoral mix of funds received by the banking system.

The reallocation of funds from the private sector to the Government reduces private investment and consumption expenditures on goods and services from what they otherwise would have been. This central bank action will not affect total spending since the funds taken from the private sector are spent by the public sector; only the sectoral mix between private and public expenditures is altered. ${ }^{12}$

Growth in real output and investment induced by increased Government expenditures will lead to a corresponding increase in the imports of capital and consumption goods, ${ }^{13}$ generating pressures on the current account of the balance of payments. Exports cannot respond rapidly in the short run since they are mainly agricultural and mining products whose low rates of growth leave a growing deficit that has to be financed with greater amounts of foreign capital inflows.

Therefore, the foreign exchange stability goal can only be accomplished in the short run by reducing imports. This implies sacrificing the development goal of economic policy.

Short-term economic policy in Mexico thus requires considerable "fine tuning" so that both the Government and balance-of-payments deficits do not fall out of a tolerable range, thus invalidating the economic policy goals.

\footnotetext{
12Total demand could be affected under these conditions only if the productivity of the Government's expenditure is considerably different from that of the private sector. In this case, the Mexican economy as a whole would be worse off after the sectoral reallocation.

${ }^{13}$ The marginal propensity to import is greater for the government than the private sector, and the import demand is inelastic.
}

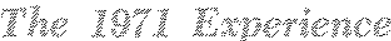

By the end of 1970 , it was recognized that high rates of economic growth for more than a decade had built up a very important destabilizing force in the economy that could no longer be overlooked. The current account deficit in the balance of payments surpassed $\$ 900$ million $-\$ 200$ million more than the level considered consistent with the other economic policy objectives. Government deficits had also been growing constantly, absorbing larger shares of private bank savings and deteriorating the structure of the Government's foreign debt position with higher interest rates and shorter terms of maturity.

These pressures were endangering two of the overall goals of economic policy - that is, the stability of both domestic prices and the rate of exchange. It was argued also that the failure to attain these goals would jeopardize the future growth of the Mexican economy as well as the goals of full employment and more equitable income distribution.

Also, developments in world markets were exerting pressures on the Mexican economy. These included the international financial crisis, a reduction of domestic demand in some industrialized countries, and inflationary conditions prevailing in international markets.

Therefore, policymakers decided to stop the "overheating" of the economy through a restrictive program in 1971. Government expenditures were reduced drastically, especially investment expenditures; legal reserve requirements were raised; the rate of growth of money was reduced to an 8.6 percent annual rate from the average 11 percent of the preceding years; and more aggressive measures were taken to promote additional exports and reduce imports.

The results of these measures were felt promptly and the pressures that threatened the balance of payments and domestic prices were reduced. However, the effects on growth surpassed the policymakers' expectations as the rate of real GDP growth fell from 7.7 percent in 1970 to 3.7 percent in 1971 - a far more drastic contraction than was expected. The implicit price deflator growth rate was reduced from 5 percent in 1970 to only 4 percent by the end of 1971 .

The slowing in economic activity permitted imports to grow only 0.6 percent during 1971 in comparison with 17.6 percent in 1970 . As a result, the current account deficit was $\$ 200$ million smaller than that of 1970. Excess reserves of private banks increased by 
more than two billion pesos during the year. The demand for credit was reduced at the prevailing level of interest rates due to apparent adverse expectations or increased uncertainty introduced by the "recession."

In 1972 less restrictive policy actions were adopted and the economy showed a well-defined move towards recovery. Prices began increasing moderately and the outlook for the balance of payments and the Government deficit improved. It seems that the political price the Mexican policymakers had to pay for this change in the trend of the Mexican economy was worth the effort. The question remaining is whether the 1971 experience was a permanent setback or whether structural changes are required so that the goals of economic policy can be reconciled.

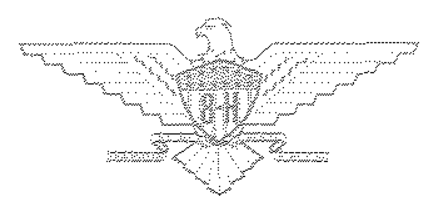

\title{
Publications of This Bank Include:
}

\author{
Weekly \\ U.S. FINANCIAL DATA
}

Monthly

REVIEW

MONETARY TRENDS

NATIONAL ECONOMIC TRENDS

Quarterly

\author{
QUARTERLY ECONOMIC TRENDS \\ SELECTED ECONOMIC INDICATORS - CENTRAL \\ MISSISSIPPI VALLEY \\ FEDERAL BUDGET TRENDS \\ U. S. BALANCE OF PAYMENTS TRENDS
}

Annually

\author{
ANNUAL U.S ECONOMIC DATA \\ RATES OF CHANGE IN ECONOMIC DATA \\ FOR TEN INDUSTRIAL COUNTRIES \\ (QUARTERLY SUPPLEMENT)
}

Copies of these publications are available to the public without charge, including bulk mailings to banks, business organizations, educational institutions, and others. For information write: Research Department, Federal Reserve Bank of St. Louis, P. O. Box 442, St. Louis, Missouti 63166. 